\title{
Case Study: Ethical Considerations of an Accounting Professional
}

\author{
Valeriya Avdeev \\ William Paterson University \\ Sia Nassiripour \\ William Paterson University \\ Hannah Wong \\ William Paterson University
}

This manuscript will provide a detailed approach to ethical business decision making that can be used as a guide to approach even the most intricate and sensitive business issues. It will examine a variety of different ethical issues that will apply to business practitioners in various fields and markets. The reader will be able to examine and then apply the available guidance and standards to a variety of ethical business dilemmas to better understand how to respond to everyday ethical concerns and to address them effectively despite a heavy work load and an inherent loyalty to one's client.

\section{INTRODUCTION}

Any accounting professional is faced with complex ethical dilemmas on a daily basis. Moreover, actions and decisions of an accountant are more transparent and visible then they were several years ago. In the wake of technological growth, a typical accountant is responsible to not only sufficiently manage her client responsibilities with ever growing demand for adequate compliance, but also to timely recognize and address any relevant ethical considerations. Today, the concept of ethics has evolved to include image and reputation. With recent scandals such as Wells Fargo employees creating fake accounts for actual employees to inflate annual bonuses and pharmaceutical Mylan that imposed heavy price increases for its customers who used an often life-saving EpiPen, the need to identify and resolve ethical dilemmas is more evident than ever before. When faced with an ethical dilemma, there are several steps that should be followed to resolve the issue at hand (Matthews, et.al., 2016). This paper will examine those steps and provide a detailed approach to ethical decision-making that can be used as a guided approach even in the most intricate and sensitive ethical business dilemmas.

\section{RELEVANT FACTS}

Jane Doe is a newly-promoted partner at Doe \& Young, LLC. Doe and Young is a three-partner CPA firm. In 2014, Jane's firm had signed an engagement letter to preparer tax returns for a young, but very successful and fast-growing company Trade Race, Inc. Trade Race had started trading with a handful of 
employees, but now has grown to have 102 employees. Jane works very hard and always places her clients first. Soon, she develops a very close relationship with the directors of Trade Race, who are also its majority shareholders. Through her encounters and discussions with the directors of Trade Race, Jane becomes aware that any fees collected from employee accounts at the company are processed outside of the company's accounting system. The funds that accumulate throughout the year from those fees are then used to fund the company's holiday party at the end of the year. Jane has just been invited to attend such holiday party.

\section{IDENTIFYING AN ETHICAL DILEMMA}

Once Jane becomes aware of the ethical dilemma, she must evaluate its consequences and preparer a plan of action. Specifically, Jane realized that Trade Race improperly accounts for the trading fees paid by its own employees. Such actions will result in underreporting of company's income and will have both GAAP and tax consequences.

\section{SEEKING GUIDANCE}

\section{Firm-Specific Code of Ethics or Business Conduct}

Generally, every firm has its own Code of Ethics or Code of Business Conduct. Moreover, larger entities also have an ethics officer or an ethics hotline that employees can use as an anonymous resource. A firm-specific Code of Ethics is a perfect place to address one's initial concerns since that Code will be drafted specifically with the firm in mind taking into account the intricacies of the market place and specific duties that employees will be responsible for. A typical Code of Ethics will address fundamental principles such as integrity, objectivity, professional competence and due care, and professional behavior (PILOT). Depending on the complexity of the business and the level of client-interaction, the Code could also include such important ethical considerations, including:

1. Financial conflicts of interest

2. Conflicts between competing values

3. Conflicts between competing duties

4. Conflicts over long-term versus short-term outcomes

5. Conflicts between interests of shareholders and interests of the business

6. Privacy concerns over big data accumulation and storage

7. Compliance and adequate disclosure considerations

8. Internal employee considerations

Moreover, some Codes of Ethics or Code of Business Conduct even include examples of ethical dilemmas and a sample plan to address them. For example, The CocaCola Company, in its Code of Business Conduct, lists an example of appropriate usage of company assets, including cellphone use (CocaCola Code of Conduct). It states: "Use common sense. For example, the occasional personal phone call or e-mail from your workplace is acceptable. Excessive personal calls or e-mail is a misuse of assets." (CocaCola Code of Conduct, p.13). The Code Business Conduct by CocaCola sites eighteen different examples of appropriate or inappropriate behavior that are very useful to the user (CocaCola Code of Conduct, p.13). One other notable example includes a marketing director that wishes to disclose potentially confidential information to his students. The Code provides: "I am a marketing manager and have volunteered to teach a course on marketing at a local college. I believe that my students would benefit from a discussion of how the Company developed several marketing campaigns. Can I discuss this work in class? A: Only with prior approval from your Local Ethics Officer. The development of marketing campaigns is a Company work product and a Company asset. Much of this work may be proprietary, and may not be appropriate to reveal outside the Company." (CocaCola Code of Conduct, p.15). CocaCola's Code of Conduct even addresses insider trading: "I have learned that the Company is considering the acquisition of a small, publicly-traded beverage company. May I acquire the stock of this company in anticipation of the acquisition? A: No. Trading on material nonpublic information is illegal 
and a violation of the Code, whether you are trading in the stock of The Coca-Cola Company or the stock of another company." (CocaCola Code of Conduct, p.18). Another company who's Code of Conduct includes examples for its employees is Alphabet, Google's parent company (Google Code of Conduct). To avoid potential conflicts of interest, the Code advises: "You should never approve Google accounts, services, or credits for yourself, your friends, or family members. Similarly, you should not use the tools, information, or access that you have as a Googler to participate in or to generate a financial benefit for yourself or others from invalid ad traffic (IVT) on Google products, such as generating IVT, purchasing or selling IVT (except for the purposes of company sanctioned research), or linking to (or appearing to link to) business partners that may be engaging in IVT." (Google Code of Conduct). If an employee encountered a conflict of interest ethical issues, the Code directs the following action: "If you find yourself subject to a conflict of interest regarding the use of Google's products, services, tools, or information, discuss the situation with your manager, Legal, or Ethics \& Compliance." (Goggle Code of Conduct). Hersey's Code of Conduct from the title sends a clear message to those employed - In the Good Company (Hershey's Code of Conduct). It too has several example of unethical behavior that it instills in its employees: "Giving anything of value to a government official can be problematic. Always ask for help from the Law Department if the right thing to do is unclear." (Hershey's Code of Conduct, p.18). Starbucks Company similarly has a Code of Conduct to promote ethical behavior in its workplace (Starbucks Business and Ethics Compliance). The Code lists several examples where conflict of interest can arise:

- Being employed by or operating a firm, including consulting, that does or desires to do business with Starbucks or that competes with Starbucks (for example, working in a competitor's coffee shop)

- Making a substantial direct investment in such a firm (by you or a member of your immediate family)

- Acting on behalf of anyone besides Starbucks in any transaction with Starbucks (for example, helping someone sell products and/or services to Starbucks)

- Engaging personally in transactions in which Starbucks has an interest (Starbucks Business and Ethics Compliance at p. 15).

Likewise, Facebook has a Code of Conduct that seeks to guide its users and employees (Facebook Code of Conduct). Although posted online relatively recently, on June $5^{\text {th }}$ of 2018 , the Code is very comprehensive and seeks to cover a variety of topics including:

- Conflict of Interest

- Harassment

- Communications

- Public Disclosures

- Financial Integrity and Responsibility

- Confidential Information

- Protection of User Data and Personnel Data

- Protection and Use of Facebook Assets

- Compliance with Laws

- Reporting Violations

- Policy Prohibiting Retaliation

The Facebook Code of Conduct, however, does not provide any example of unethical behavior (Facebook Code of Conduct). Under Armour, on the other hand, offers helpful examples to its employees and also sends a clear message from the cover of its Code of Conduct - Protect This House - Make the Right Call (Under Armour Code of Conduct). Most importantly, Under Armour's Code of Conduct addresses a very important stage for potential ethical issues - social media: "Be careful when discussing UA on social media. Don't speak on behalf of UA on your personal social media accounts, and always keep in mind confidential company matters and the protection of others." (Under Armour Code of Conduct). Moreover, even helpful examples are offered: "For example, don't post new UA product 
offerings, new UA assets or other sensitive UA marketing information that has not yet been publicly announced. When in doubt...just don't post. Contact HR or refer to the policy if you have questions." (Under Armour Code of Conduct). Finally, Microsoft offers a Standards of Business Conduct that can be instantaneously translated into eighteen different languages (Microsoft Code of Conduct). The Code is very comprehensive with a main message that states - Lead by Example (Microsoft Code of Conduct).

\section{Counseling with a Senior or Mentor}

Once consulted with the firm-specific Code of Ethics or Code of Business Conduct, it is always best to reach out to a mentor or senior supervisor to seek their guidance and advice. Working in the same field, they would be best equipped to not only steer you in the right direction, but also offer some personal advice or experience. Your mentor or advisor will also be able to communicate and identify possible ethical questions at hand.

\section{Counseling with Internal Corporate Counsel or Legal Department}

In most complex ethical dilemmas, it is best to contact the firm's legal department as soon as possible. Most causes of action have a very brief statute of limitations. As the result, in a true legal emergency, it is not only important to identify such legal issues promptly, but also to act within a necessary time window. Legal department is best equipped to deal with such complex ethical dilemmas that often times also have significant legal implications.

\section{Code of Professional Conduct - AICPA}

Moreover, every licensed profession generally has a Code of Professional Conduct that is specific to the issue at hand. For example, a certified public accountant would have to refer to the AICPA's Code of Professional Conduct (AICPA Code of Conduct). Therefore, as a licensed CPA, Jane would have to refer and comply with the Code. Specifically, when referring to Rule 501 of the Code, Jane will acknowledge that she is prohibited from committing acts that are discreditable to the profession (AICPA Code of Conduct). Among the discreditable acts are making false or misleading entries or not correcting such entries if the member has the authority to do so (AICPA Code of Conduct). Among other discreditable acts are signing a materially false or misleading document and allowing or directing others to make such entries or sign such documents (AICPA Code of Conduct). Therefore, once consulting the AICPA's Code of Professional Conduct, Jane will realize that she will be in violation of Rule 501 if she ignores her findings and continues to sign the client's tax returns. As the result, she must act promptly to address the ethical dilemma at hand.

\section{Documenting Decisions - Memorandum to File}

Finally, as a licensed CPA, Jane is required to document such ethical dilemmas properly. Specifically, Jane would need to consult all of the available resources mentioned above and to come up with a plan of action with a resolution. Once she has a clear plan of action, Jane needs to draft a memorandum to file to protect herself, her license and her firm against potential further ethical or legal implications.

\section{A PLAN OF ACTION}

After consulting all of the resources listed above, Jane Doe needs to create a plan of action and follow-through. First, Jane needs to inform the other partners in the firm that client is inadequately accounting for fees collected on investment accounts from employees. By accumulating these fees outside of the company's accounting system, the client is underreporting their income. Such underreporting undoubtedly effects their book income and tax returns. Second, even though Jane is invited to the client's Christmas party, she needs to inform the client that a staff accounts policy needs to be instituted that includes fee-recognition from staff fees. Jane needs to inform her client that such practice violates GAAP and Internal Revenue Code. Third, Jane needs to consult with her other partners in regards to the possibility of having to amend prior year tax returns to include employee fees. Fourth, Jane also need to 
assess the implication of such changes on the client's financial statements and on the possibility of having to re-state financial statements depending on materiality. Finally, after consulting with her peer-partners, Jane needs to also evaluate the possibility of having to dissociate from the client's firm, especially if the client resists suggested changes.

\section{REFERENCES}

AICPA Code of Professional Conduct (n.d.). Retrieved May 22, 2019, from https://www.aicpa.org/research/standards/codeofconduct.html

Coca-Cola Code of Conduct (n.d.). Retrieved May 22, 2019, from https://www.cocacolacompany.com/content/dam/journey/us/en/private/fileassets/pdf/2018/CocaCola-COC-External.pdf

Facebook Code of Conduct (n.d.). Retrieved May 22, 2019, from https://investor.fb.com/corporategovernance/code-of-conduct/default.aspx

Goggle Code of Conduct found (n.d.) Retrieved May 5, 2019, from https://abc.xyz/investor/other/googlecode-of-conduct.html

Hershey Code of Conducts found (n.d.). Retrieved May 22, 2019, from https://www.thehersheycompany.com/content/dam/corporate-us/documents/investors/code-ofconduct.pdf

Matthews, C., \& Heiner, M. (2016, December 28). The 5 Biggest Corporate Scandals of 2016. FortuneFinance.

Microsoft Code of Conduct found (n.d.). Retrieved May 22, 2019, from https://www.microsoft.com/enus/legal/compliance/sbc/download

PILOT Code of Ethics and Business Conduct (n.d.). Retrieved May 21, 2019, from https://pilotpen.us/images/custom/CodeofEthics.pdf

Starbucks Business and Ethics Compliance (n.d.) Retrieved May 22, 2019, from https://globalassets.starbucks.com/assets/eecd184d6d2141d58966319744393d1f.pdf

Under Armour Code of Conduct found (n.d.). Retrieved May 22, 2019, http://investor.underarmour.com/static-files/fdd4d03e-a31e-49a4-9500-88c4a0abcb80 